\title{
Assessment of Lead, Arsenic and Cadmium in Tilapia Guineensis and Sarotherodon Melanotheron Found in Bodo River
}

\section{Regina $\mathrm{OE}$ and Kingsley $\mathrm{ON}^{*}$}

Department of Pure and Industrial Chemistry, University of Port Harcourt, Nigeria

*Corresponding author: Owhonda N Kingsley, Department of Pure and Industrial Chemistry, University of Port Harcourt, Nigeria, Email: kingsleyndubuisiowhonda@gmail.com

\section{Research Article \\ Volume 1 Issue 1}

Received Date: July 20, 2016

Published Date: August 08, 2016

\section{Abstract}

Due to several reports of pollution in Ogoni land, this study was carried out to determine how safe these fish species are for human consumption. The amounts of lead, arsenic and cadmium in the flesh of Tilapia guineensis and Sarotherondon melanotheron found in Bodo River were studied using X-ray fluorescence (XRF). The amount of lead found in the two fish species ranged between $3.2-5 \mathrm{mg} / \mathrm{kg}$, arsenic $1.8-2.1 \mathrm{mg} / \mathrm{kg}$ and cadmium $0.6-2 \mathrm{mg} / \mathrm{kg}$ and were higher than tolerable limits recommended by health agencies. The amounts of these elements show that these fish species from this location are unsafe for human consumption.

Keywords: Lead; Arsenic; Cadmium; Tilapia guineensis, Sarotherondon melanotheron; Bodo river

\section{Introduction}

Hutton [1] stated that lead, mercury, arsenic and cadmium have caused major human health problems in several parts of the world. Due to several years of oil exploration and exploitation in Ogoni land there has been several reports stating how badly damaged the entire environment is. In recent times, the Federal Government of Nigeria invited the United Nations Environment Programme (UNEP) to independently study Ogoni Environment and make recommendations. The summary of that report is presented in UNEP Job number DEP/1337/GE. The summary of the report is that Ogoni environment is heavily polluted and needs cleaning. However, few studies are available on the safety of consuming specific fish species. Some examples of this study include those by Jumbo et al. [2] and Kpobari et al. [3].
In trace amounts many elements are useful to the human body but in large amounts they cannot be excreted and thus, bio-accumulate in the body interfering with enzyme activities thus, hindering many body functions [4]. On the other hand, no amount of some particular element is considered safe. It is important to constantly study the amount of elements in fishes found in various water bodies especially, in polluted areas because people depend on fish as a major source of protein. However, overtime these fishes accumulate some dangerous elements from the surrounding water to an amount hundreds or thousands of times higher than the surrounding water [5].

\section{Materials and Method}

\section{Study area}

Bodo community is a part of Ogoni land in Gokana Local Government area of Rivers State. Ogoni land has had 
several incidents of oil spill and oil well fires leading to serious environmental pollution. According to Kpobari et al. [3] Ogoni land covers $1,000 \mathrm{~km}^{2}$ in the South-East of the
Niger Delta basin (Figure 1) with a population of 832,000 consisting mainly of Ogoni people.
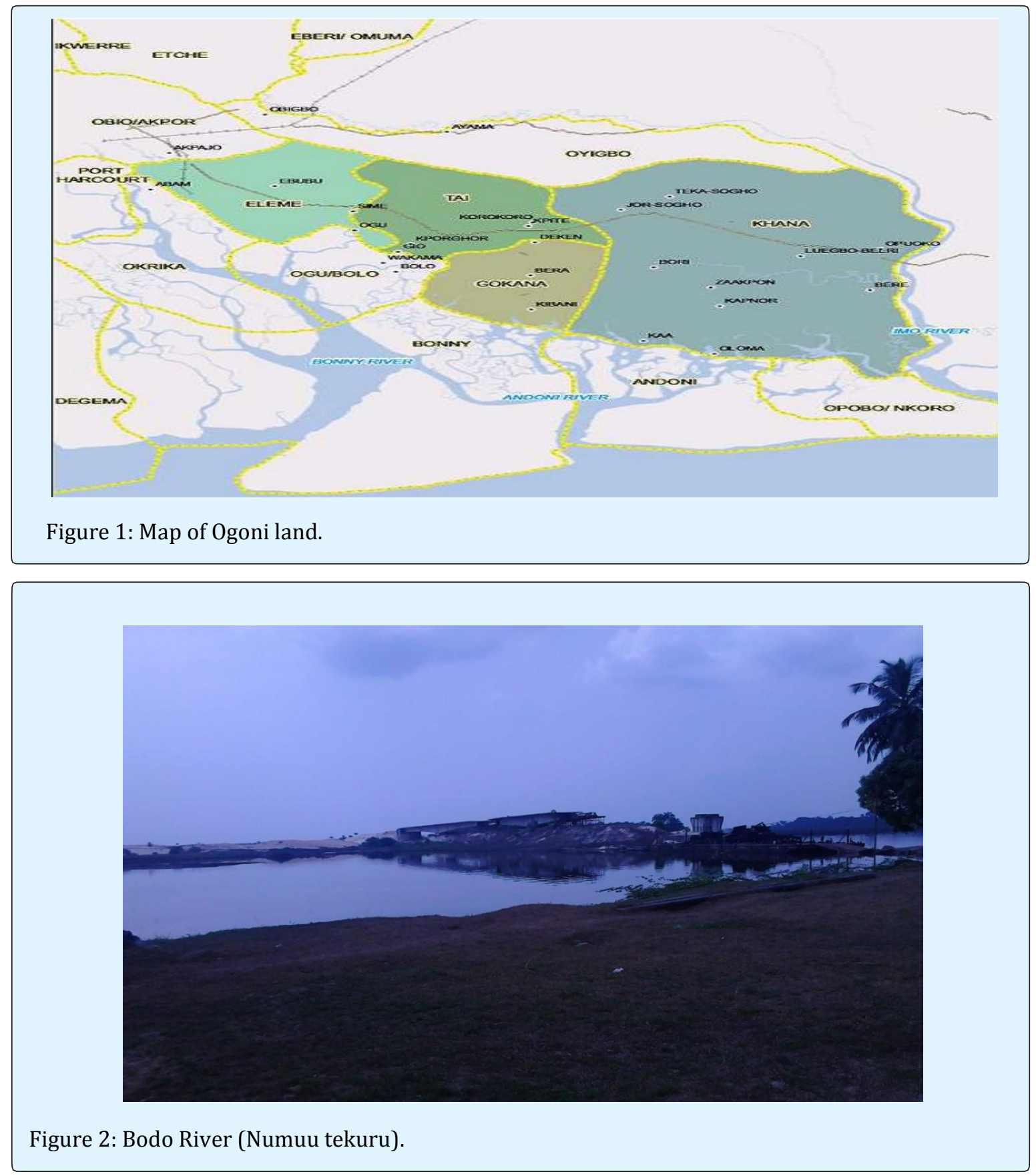


\section{International Journal of Oceanography \& Aquaculture}

\section{Collection of test samples}

The fresh samples of Tilapia guineensis and Sarotherdon melanotheron were collected from Bodo River (Figures 3 \& 4). This river is popularly known by the dwellers as "Numuu tekuru". Identity of the fish species was confirmed at the Nigerian Institute for Oceanography and Marine Research fish farm, Buguma. Five table size of each fish species were collected, cleaned, wrapped in aluminium foil and put into ice. The entire content was put in a black polyethylene bag and carried in a cooler for analyses.

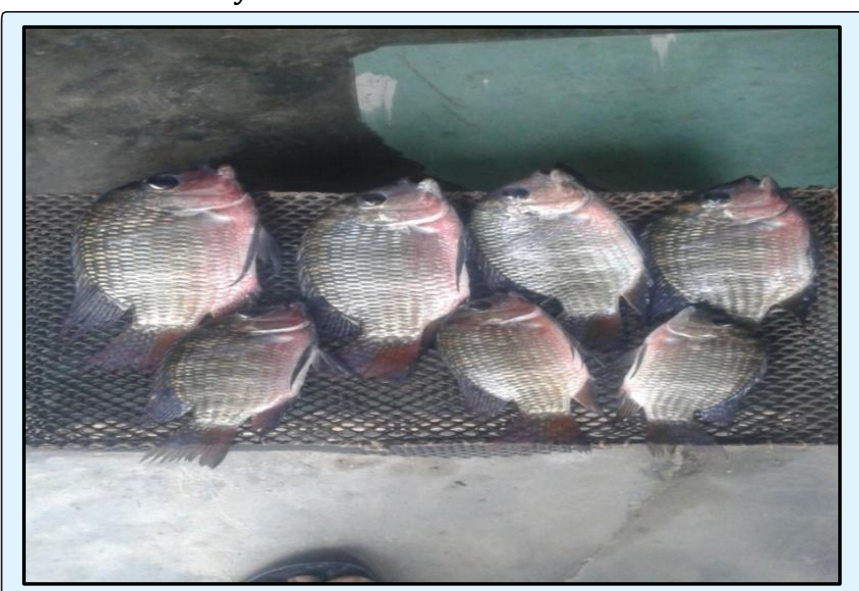

Figure 3: Tilapia guineensis.

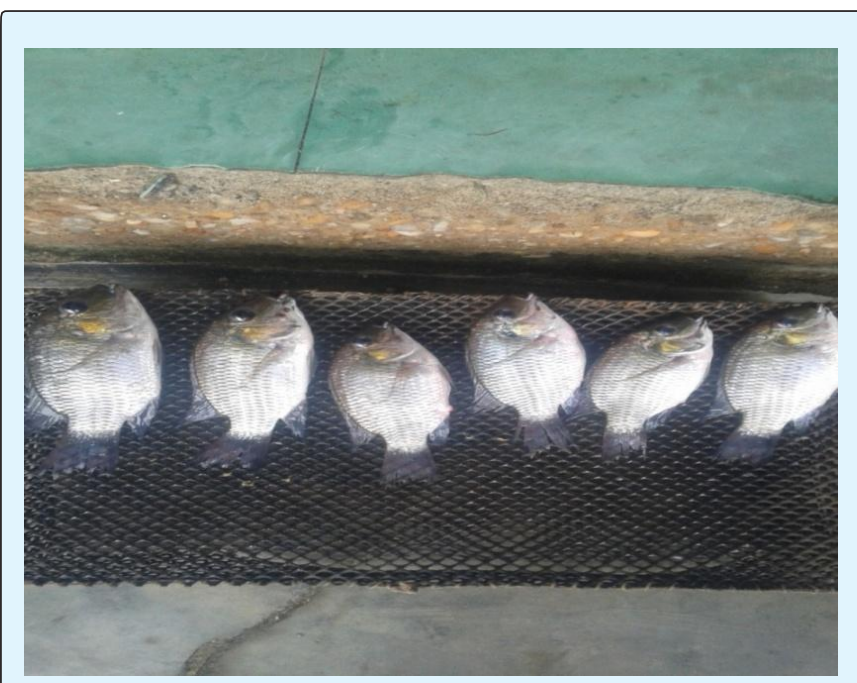

Figure 4: Sarotherodon melanotheron.

\section{Reagents}

Analytical grade reagents of high purity were used in the analyses of samples.

Kingsley ON, et al. Assessment of Lead, Arsenic and Cadmium in Tilapia Guineensis and Sarotherodon Melanotheron Found in Bodo River. Int J Oceanogr Aquac 2016, 1(1): 000102.

\section{Determination of elements}

The amount of lead, arsenic and cadmium were determined using X-ray fluorescence spectrometer in accordance with USEPA 6200. Fish samples were oven dried at $110^{\circ} \mathrm{C}$ for twenty hours. With the unwanted material like bones of fish etc removed, the fleshy part of the sample was reduced to less than $2 \mu \mathrm{m}$ diameter by crushing. Crushed samples were further pulverized (i.e. crushed until it becomes powder). They were then processed into pressed pellets, transferred to clean prolene foil and then into a sample vial, labelled, arranged in the sample tray and finally transferred to the sample compartment of the X-ray fluorescence equipment (SpectroX-LabPro) and screened for their elemental composition. The concentration of each element was obtained via a previously stored calibration with certified reference materials. Results were calculated automatically as the necessary sample details were computed in the software.

\section{Results}

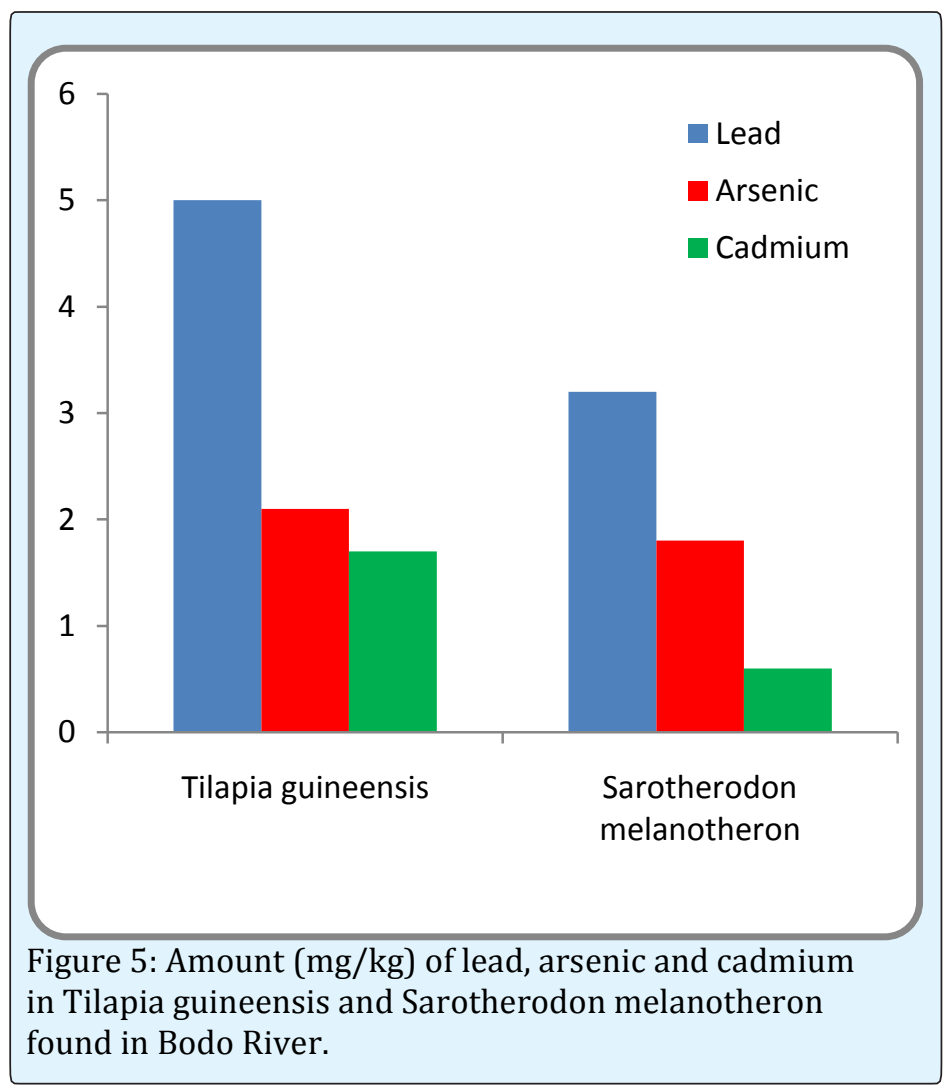




\section{International Journal of Oceanography \& Aquaculture}

\section{Discussion}

\section{Lead}

Out of the two fish species that were studied Tilapia guineensis was found to contain more lead than Sarotherondon melanotheron (Table 1). The amount of lead found ranged between $3.2-5 \mathrm{mg} / \mathrm{kg}$. It is well known that lead accumulates in the body and affects many body systems. It is particularly harmful to children. On entering the body lead is distributed to the brain, liver, kidney and bones [6]. However, overtime it accumulates mainly in the teeth and bones. There is no known level of lead exposure that is considered safe [7]. Therefore, lead toxicity through the consumption of any of these two fish species is possible.

\begin{tabular}{|c|c|c|c|}
\hline Fish Specie & $\begin{array}{c}\text { Lead } \\
\text { (mg/kg) }\end{array}$ & $\begin{array}{c}\text { Arsenic } \\
\text { (mg/kg) }\end{array}$ & $\begin{array}{c}\text { Cadmium } \\
\text { (mg/kg) }\end{array}$ \\
\hline $\begin{array}{c}\text { Tilapia } \\
\text { guineensis }\end{array}$ & 5 & 2.1 & 1.7 \\
\hline $\begin{array}{c}\text { Sarotherodon } \\
\text { melanotheron }\end{array}$ & 3.2 & 1.8 & 0.6 \\
\hline
\end{tabular}

Table 1: Amount (mg/kg) of lead, arsenic and cadmium in Tilapia guineensis and Sarotherodon melanotheron found in Bodo River.

\section{Arsenic}

The highest amount of arsenic observed in this research work was in Tilapia guineensis (Table 1). The range of arsenic found in both fish species is 1.8$2.1 \mathrm{mg} / \mathrm{kg}$. According to FAO/WHO [8] and WHO [7], there is no known tolerable limit for arsenic in food. However, WHO [9] recommends staying within drinking water limit of $10 \mu \mathrm{g} / \mathrm{l}$ per day. Therefore, both fish species are unsafe.

\section{Cadmium}

The amount of cadmium found ranged between 0.6$1.7 \mathrm{mg} / \mathrm{kg}$. Tilapia guineensis was found to contain more cadmium than Sarotherodon melanotheron. WHO [9] recommends that the maximum safe amount of cadmium per month is $25 \mu \mathrm{g} / \mathrm{kg}$ body weight. This means that an adult weighing $60 \mathrm{~kg}$ should not take more than $1.5 \mathrm{mg}$ of cadmium per month. This amount of cadmium is derivable from 882g of Tilapia guineensis and 2,500g of Sarotherodon melanotheron. This means that a person weighing $60 \mathrm{~kg}$ should only consume $882 \mathrm{~g}$ or $2,500 \mathrm{~g}$ of Tilapia guineensis and Sarotherodon melanotheron respectively per month. This is also similar to $29 \mathrm{~g}$ or $83 \mathrm{~g}$ of Tilapia guineensis and Sarotherodon melanotheron respectively per day. The average weight of a table size of these two fish species is about $67 \mathrm{~g}$. From the figure obtained it means that less than one or at most only one table size of these two fish species should be consumed in a day (Figure 5). Since people here are poor they are likely to depend on these fishes as a major source of protein and therefore, are very likely to consume far above this amount in a day. Therefore, cadmium toxicity through the consumption of Tilapia guineensis and Sarotherodon melanotheron from Bodo River is very likely.

\section{Conclusion}

Tilapia guineensis and Sarotherodon melanotheron found in Bodo River are unsafe for human consumption. Other sources of protein are hereby recommended for especially, children.

\section{References}

1. Hutton M (1987) Human Health Concerns of lead, mercury, cadmium and arsenic. In: Hutchinson (Eds.), Lead, mercury, cadmium and arsenic in the environment (Chapter 6), John Wiley and Sons Limited, United Kingdom, p. 55-68.

2. Kpobari WN, Mathew O, Eka BE (2013) Heavy metal concentrations in four selected seafood from crude oil polluted waters of Ogoniland, Rivers State, Nigeria. Archives of Applied Science Research 5(4):97-104.

3. Jumbo A, Wegwu MO, Belonwu DC, Okerenta B M (2015) Assessment of heavy metals concentration of selected fin and shell fish from Ogoniland. Journal of Environment and Earth Science 5(18): 15-19.

4. Ogwuegbu MO, Ijioma MA (2003) Effects of Certain Heavy Metals on the Population Due to Mineral Exploitation. In: International Conference on Scientific and Environmental Issues in the Population, Environment and Sustainable Development in Nigeria, University of Ado Ekiti, Ekiti State, Nigerian, p. 8-10.

5. Osman A, Wuertz S, Mekkawy I, Exner H, Kirschbaum F (2007) Lead induced malformations in embryos of the African catfish Clarias gariepinus (Burchell, 1822). Journal of Environmental Toxicology 22 (4): 375-389. 


\section{International Journal of Oceanography \& Aquaculture}

6. WHO (2004) Lead exposure. In: Comparative quantification of health risks. Geneva, World Health Organization, 1495-1542.

7. WHO (2010) Public Health and Environment. In: Preventing disease through healthy environments. Exposure to arsenic, a Major Public Concern, 1-5.
8. FAO/WHO (2010) Summary and conclusions of the seventy-second meeting of the Joint FAO/WHO Expert Committee on Food Additives, Rome, 16-25 February 2010. Rome, Food and Agriculture Organization of the United Nations, World Health Organization, Geneva.

9. WHO (2010) Public Health and Environment. In: Preventing disease through healthy environments. Exposure to lead, a Major Public Concern, 3-6. 